\title{
Larvicidal activity of microparticles of Melissa officinalis L. essential oil (Lamiaceae) against Aedes aegypti (Diptera, Culicidae)
}

Atividade larvicida de micropartículas do óleo essencial de Melissa officinalis L. (Lamiaceae) frente Aedes aegypti (Diptera, Culicidae)

Actividad larvicidal de micropartículas de Melissa officinalis L. aceite esencial (Lamiaceae) contra Aedes aegypti (Diptera, Culicidae)

Thércia Gabrielle Teixeira Martins ORCID: https://orcid.org/ 0000-0002-0506-1748

Universidade Federal do Maranhão, Brazil E-mail: thercia.martins@hotmail.com

Paulo Victor Serra Rosa ORCID: https://orcid.org/0000-0003-1782-5896

Universidade Federal do Maranhão, Brazil E-mail: paullovictorserra@gmail.com

Mariana Oliveira Arruda

ORCID: https://orcid.org/0000-0001-7097-7843 Faculdade Maurício de Nassau, Brazil

E-mail: mariana_o.arruda@yahoo.com.br

Andressa Almeida Santana Dias

ORCID: https://orcid.org/0000-0002-1671-8338 Faculdade Maurício de Nassau, Brazil E-mail: andressasantana@gmail.com Ari Pereira de Araújo Neto ORCID: https://orcid.org/ 0000-0001-6903-4127 Faculdade Maurício de Nassau, Brazil E-mail: aripereiraneto@gmail.com

Ana Maria Almeida Silva Carvalho ORCID: https://orcid.org/ 0000-0002-2075-5780

Universidade Federal do Maranhão, Brazil E-mail: aninha_biomed@yahoo.com.br

Leila da Silva Silveira

ORCID: https://orcid.org/ 0000-0003-1050-4483

Universidade Federal do Maranhão, Brazil E-mail: alielarcanjo@hotmail.com

Francilidia Oliveira Vitorino de Assunção Conceição ORCID: https://orcid.org/ 0000-0002-0079-7502

Universidade Federal do Maranhão, Brazil

E-mail: francilidiaassuncao@gmail.com

Carlos Eduardo Pereira Conceição ORCID: https://orcid.org/ 0000-0002-67359291 Hospital Guarás, Brazil

E-mail: dudaecarol21@gmail.com

Ricardo Teixeira de Sousa ORCID: https://orcid.org/ 0000-0001-9304-507X LabMed e BioSaude, Brazil

E-mail: ric.teix.sousa@gmail.com Nestor Everton Mendes Filho ORCID: https://orcid.org/ 0000-0003-2613-6347 Universidade Federal do Maranhão, Brazil

E-mail: nestoreverton@ hotmail.com

Victor Elias Mouchrek Filho

ORCID: https://orcid.org/ 0000-0003-2855-7292

Universidade Federal do Maranhão, Brazil E-mail: victor.mouchrek@ufma.br

Gustavo Oliveira Everton

ORCID: https://orcid.org/ 0000-0002-0457-914X

Universidade Federal do Maranhão, Brazil

E-mail: gustavooliveiraeverton@gmail.com 


\begin{abstract}
This study aimed to evaluate the larvicidal activity of essential oil microparticles (EO) of Melissa officinalis L. against Aedes aegypti. The leaves of $M$. officinalis were collected in the municipality of São José de Ribamar, Maranhão, Brazil, later dried, crushed and ground. $90 \mathrm{~g}$ of the dried leaves were used to obtain the EO by the hydrodistillation method. For the synthesis of microencapsulated EO, $60 \mathrm{~g}$ of sodium alginate $(2.5 \% \mathrm{~m} / \mathrm{v})$ was added to the mixture of $15 \mathrm{~g}$ of Tween 20 with $6 \mathrm{~g}$ of EO. The mixture was homogenized and drips over $\mathrm{CaCl}_{2} 5 \% \mathrm{~m} / \mathrm{v}$ solution for the hardening of particles via crosslinking. The microparticles were washed with distilled water in filter and dried at $35^{\circ} \mathrm{C} / 24 \mathrm{~h}$ and 15 days at $\mathrm{t}_{\mathrm{amb}}\left(30^{\circ} \mathrm{C}\right)$. The eggs of Aedes aegypti were collected at the Federal University of Maranhão by the ovitrampas method. The larvae that hatched were fed until they reached the fourth instar. Groups of larvae $(n=20)$ were submitted to solutions of EO and microparticles of 10-90 mg/L . After $24 \mathrm{~h}$, live and dead larvae were counted and $\mathrm{LC}_{50}$ was calculated by the Reed\&Muench method, using Cheng's criterion for classification of active potential. All larvae presented mortality in all concentrations tested. The $\mathrm{LC}_{50}$ obtained for the EO was $40.60 \mathrm{mg} / \mathrm{L}$ and for the microparticles $22.10 \mathrm{mg} / \mathrm{L}$, both classified as active according to the adopted criterion, but it is observed that the microparticles increased the larvicidal potential of the EO. Through the results obtained, it is concluded that the microparticles formulated with the EO proved to be efficient in the face of the larvae of Aedes aegypti, being interesting and important in controlling and combating the mosquito that transmits dengue.
\end{abstract}

Keywords: Bioproduct; Microparticles; Encapsulation.

\title{
Resumo
}

Este estudo teve por objetivo avaliar a atividade larvicida de micropartículas do óleo essencial (OE) de Melissa officinalis L. frente Aedes aegypti. As folhas de M. officinalis foram coletadas no município de São José de Ribamar, Maranhão, Brasil, posteriormente secas, trituradas e moídas. Foram utilizadas 90g das folhas secas para obtenção do OE pelo método de hidrodestilação. Para a síntese do OE microencapsulado, $60 \mathrm{~g}$ de alginato de sódio $(2,5 \% \mathrm{~m} / \mathrm{v})$ foram adicionados a mistura de $15 \mathrm{~g}$ de Tween 20 com $6 \mathrm{~g}$ do OE. A mistura foi homogeneizada e gotejada sobre solução de $\mathrm{CaCl}_{2} 5 \% \mathrm{~m} / \mathrm{v}$ para o endurecimento das partículas via crosslinking. As micropartículas foram lavadas com água destilada em filtro e secas à $35^{\circ} \mathrm{C} / 24 \mathrm{~h}$ e 15 dias à $\mathrm{t}_{\mathrm{amb}}\left(30^{\circ} \mathrm{C}\right)$. Os ovos de Aedes aegypti foram coletados na Universidade Federal do Maranhão pelo método de ovitrampas. As larvas que eclodiram foram alimentantadas até atingirem o quarto ínstar. Submeteu-se grupos de larvas $(\mathrm{n}=20)$ a soluções do OE e das micropartículas de 10-90 mg/L . Após $24 \mathrm{~h}$ contou-se as larvas vivas e mortas e calculou-se a CL50 pelo método de Reed\&Muench, utilizando o critério de Cheng para classificação do potencial ativo. Todas as larvas apresentaram mortalidade em todas as concentrações testadas. A CL 50 obtida para o OE foi de $40,60 \mathrm{mg} / \mathrm{L}$ e para as micropartículas $22,10 \mathrm{mg} / \mathrm{L}$, ambos classificados como ativos segundo o critério adotado, porém observa-se que as microparticulas aumentaram o potencial larvicida do OE. Através dos resultados obtidos, conclui-se que as microparticulas formuladas com o OE revelaram-se eficientes frente às larvas de Aedes aegypti, sendo interessante e importante no controle e combate ao mosquito transmissor da dengue.

Palavras-chave: Bioproduto; Micropartículas; Encapsulamento.

\section{Resumen}

Este estudio tuvo como objetivo evaluar la actividad larvicida de las micropartículas de aceite esencial (AE) de Melissa officinalis L. frente Aedes aegypti. Las hojas de M. officinalis fueron recolectadas en el municipio de San José de Ribamar, Maranhao, Brasil, más tarde secas, trituradas y molidas. 90g de las hojas secas se utilizaron para obtener la AE por el método de hidrodestación. Para la síntesis de AE microencapsulado, se añadieron $60 \mathrm{~g}$ de alginato de sodio (2,5\% $\mathrm{m} / \mathrm{v}$ ) a la mezcla de $15 \mathrm{~g}$ de Tween 20 con $6 \mathrm{~g}$ de AE. La mezcla fue homogeneizada y goteada sobre la solución de $\mathrm{CaCl}_{2} 5 \% \mathrm{~m} / \mathrm{v}$ para el endurecimiento de partículas a través de reticulación. Las micropartículas se lavaron con agua destilada en filtro y se secaron a $35 \mathrm{oC} / 24 \mathrm{~h}$ y 15 días a $\mathrm{t}_{\mathrm{amb}}\left(30^{\circ} \mathrm{C}\right)$. Los huevos de Aedes aegypti fueron recogidos en la Universidad Federal de Maranhão por el método ovitrampas. Las larvas que eclosionaron fueron alimentadas hasta que llegaron a la cuarta estrella. Se sometieron grupos de larvas (n-20) a soluciones de E/S y micropartículas de 10-90 mg/L. Después de $24 \mathrm{~h}$, se contaron larvas vivas y muertas y la $\mathrm{LC}_{50}$ fue calculada por el método Reed\&Muench, utilizando el criterio de Cheng para la clasificación del potencial activo. Todas las larvas presentaron mortalidad en todas las concentraciones analizadas. $\mathrm{El} \mathrm{LC}_{50}$ obtenido para la $\mathrm{EO}$ fue de $40,60 \mathrm{mg} / \mathrm{L}$ y para las micropartículas $22,10 \mathrm{mg} / \mathrm{L}$, ambos clasificados como activos según el criterio adoptado, pero se observa que las micropartículas aumentaron el potencial larvicida de la AE. A través de los resultados obtenidos, se concluye que las micropartículas formuladas con la EO demostraron ser eficientes frente a las larvas de Aedes aegypti, siendo interesantes e importantes en el control y la lucha contra el mosquito que transmite el dengue.

Palabras clave: Bioproducto; Micropartículas; Encapsulación. 


\section{Introduction}

Microencapsulation is a technique used as a tool for protection and modulation of the release of substances. It has been successfully applied to the protection of substances sensitive to temperature, oxidation, moisture and undesirable reactions, allowing microencapsulated products to have better potential for use (Ozório et al., 2007).

Active substances of plant origin, such as monoterpenes and their complex mixtures (essential oils) have a variety of properties among which are of biological interest, such as potential larvicides in the control of arboviruses vectors. However, some limitations related to the stability of these substances and their mixtures can be observed in the direct use of a general form (rapid volatilization, oxidation of the chemical constituents of the oil, among others). These limitations can be addressed with the use of carrier systems, such as microcapsules in the control of arbovirus vectors (Gonsalves et al., 2009).

Among the arboviruses that are difficult to control is dengue, one of the main public health problems in the world, being transmitted by Aedes aegypti. Accelerated growth was also reported in cases of other diseases from Aedes aegypti, such as Zika and Chikungunya (Silva et al., 2018). It is noteworthy that even with technological advances in the search for vaccines for these diseases, only for yellow fever there is a long-term vaccine, approximately 10 years (Rothman, 2004). Thus, the best method of control is prevention, attacking its urban vector (Govindarajan, 2013).

Vector control is performed by eliminating sites for oviposition or elimination of larvae (Coller, 2011). Among the methods used to control larvae, it is found that the use of organophosphate insecticide temephos is the main measure adopted by the National Program for Dengue Prevention in Brazil and the World Health Organization (Prophiro et al., 2011).

However, according to studies conducted, populations of insecticide-resistant mosquitoes have been identified in Colombia and also in several states of Brazil, such as Minas Gerais, Paraíba, Ceará and the Federal District (Horta et al., 2011). In this context, the need for alternative methods arises, especially those based on natural resources, and the insecticide should be sustainable, ecologically correct, effective, have low toxicity to mammals and should not significantly modify the characteristics of water (Dias \& Moraes, 2014), showing the importance of adding toxicity studies to non-target organisms for implementing alternative vector controls.

As a form of protection, plants produce secondary metabolites such as flavonoids, alkaloids and terpenoids that coeve with insects and microorganisms, becoming natural sources of insecticide substances (Simões et al., 2010). These substances are known as essential oils (EOs), produced in the secondary metabolism of plants, being a good source of materials with insecticide, larvicidal and repellent action (Costa et al., 2005).

With this, medicinal plants producing EOs that presented larvicide potentials in the literature, but that did not yet have studies in relation to microencapsulation using alginate or in relation to the synthesis of microparticles of EOs for larvicidal activity assays. Thus, after consulting the publicly available databases, the selection of the plant Melissa officinalis L. The choice is also justified in the view of the popular use of this plant by the almost absence of toxicity of these products to humans, animals and other plants, and by the fact that they are biodegradable, which avoids contamination of the environment (Pimenta et al., 2006).

Thus, this study aimed to determine the chemical constituents, evaluate toxicity and larvicidal activity against Aedes aegypti of EOs and microparticles of Melissa officinalis $\mathrm{L}$.

\section{Methodology}

\subsection{Collection of plant material}

The collection of plant material used in this research was carried out in Agosto 2020. The leaves of M. officinalis were collected in the municipality of São José de Ribamar, São Luís, Maranhão, Brazil. After collection, the plant material was 
transported to the Laboratory of Research and Application of Essential Oils (LOEPAV/UFMA), where it was submitted to the convective air-drying oven FANEM 520 at $45^{\circ} \mathrm{C}$ for 24 hours, and subsequently crushed in a knife mill.

\subsection{Obtaining oils}

For the extraction of EO M. officinalis, the hydrodistillation technique was used with a glass Clevenger extractor coupled to a round-bottomed balloon packed in an electric blanket as a heat generating source. $90 \mathrm{~g}$ of the dried peels of M. officinalis were used adding distilled water (1:10). Hydrodistillation was conducted at $100^{\circ} \mathrm{C}$ for $3 \mathrm{~h}$ and extracted EO was collected (Figure 1). Each EO was dried by percolation with anhydrous sodium sulfate $\left(\mathrm{Na}_{2} \mathrm{SO}_{4}\right)$ and centrifuged. These operations were performed in triplicates and the samples stored in amber glass ampoules under $4^{\circ} \mathrm{C}$ refrigeration. Subsequently submitted the analyses.

Figure 1. Essential oil obtained after 3h of extraction by hydrodistillation method.

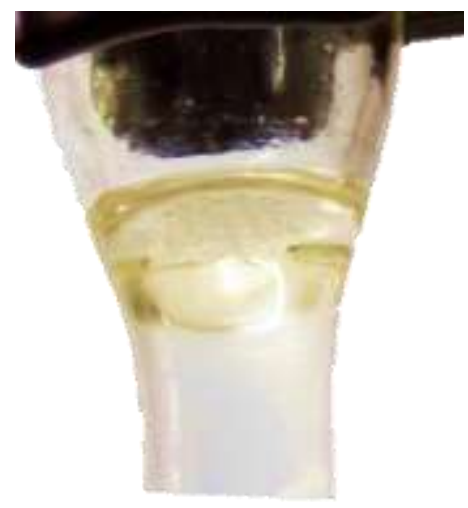

Source: Authors (2020).

\subsection{Chemical constituents}

The constituents of the EOs were identified by gas chromatography coupled to mass spectrometry (CG-MS). $1.0 \mathrm{mg}$ of the sample was dissolved in $1000 \mu \mathrm{L}$ of dichloromethane (purity 99.9\%). The conditions of analysis were as follows: Method: Adams. M, m; Injected volume: $0.3 \mu \mathrm{L}$; Column : Capillary HP-5MS (5\% diphenyl, 95\% dimethyl polysiloxane ) (Equivalent DB-5MS or CP-Sil 8CB LB/MS), in dimensions (30 m x $0.25 \mathrm{~mm}$ x $0.25 \mu \mathrm{m}$ ); Drag gas : He (99.9995); $1.0 \mathrm{~mL} \cdot \mathrm{min}^{-1}$; Gun: 280 ${ }^{\circ} \mathrm{C}$, Split mode (1:10); Oven: $40 \mathrm{oC}\left(5.0 \mathrm{~min}\right.$.) up to $240{ }^{\circ} \mathrm{C}$ at a rate of $4{ }^{\circ} \mathrm{C} \mathrm{min}^{-1}$, from $240 \mathrm{oC}$ to $300{ }^{\circ} \mathrm{C}(7.5 \mathrm{~min})$ at a rate of 8 $\left.{ }^{\circ} \mathrm{C} \cdot \mathrm{min}^{-1}\right)$; $\mathrm{tT}=60.0 \mathrm{~min}$; Detector : EM; EI $(70 \mathrm{eV})$; Scan mode $\left(0.5 \mathrm{sec} \mathrm{scan}{ }^{-1}\right)$; Mass range: 40 - 500 daltons (one); Line transfer: $280^{\circ} \mathrm{C}$.; Filament: off 0.0 to $4.0 \mathrm{~min}$; Linear quadrupole mass spectrometer. The AMDIS (Automated Mass spectral Deconvolution Mass \& Identification System) program was used to identify the compounds in the sample.

\subsection{Cultivation of Artemia salina Leach}

This test was performed according to the methodology described by Meyer et al. (1982). In a rectangular container, with a partition containing holes approximately $0.02 \mathrm{~cm}$ in diameter, spaced by $0.5 \mathrm{~cm}$ and evenly distributed, artificial saline solutions ( $60 \mathrm{~g} \mathrm{~L}^{-1}$ distilled water) (60 g salt/liter distilled water) was added. The container was placed inside an incubator illuminated by fluorescent lamp, with oxygenation. On one side of this container, about $64 \mathrm{mg}$ of Artemia salina Leach cysts were added, provided that they did not cross the partition. The part of the system containing artemia saline cysts were covered with aluminum foil, so that organisms, at birth, were attracted by light on the other side of the system, forcing them to cross the partition. This procedure aims to homogenize the physical conditions of test organisms. Incubation was performed for a period of 48 hours. The temperature was monitored throughout the bioassay. 


\subsection{Artemia salina Leach lethality test}

For the evaluation of the lethality of Artemia salina Leach (Figure 2), a saline solution was prepared stock of each EO in the concentration of $10.000 \mathrm{mg} \mathrm{L}^{-1}$ and $0.02 \mathrm{mg}$ of Tween 80 (active tense). Rates of 5, 50 and $500 \mu \mathrm{L}$ of this were transferred to test tubes and supplemented with saline solution previously prepared up to $5 \mathrm{~mL}$, obtaining at the end concentrations of 10, 100 and $1000 \mathrm{mg} \mathrm{L}^{-1}$, respectively. All tests were carried out in triplicates, where ten larvae in the nauplium phase were transferred to each of the test tubes.

Figure 2. Nauplium phase of Artemia salina Leach.

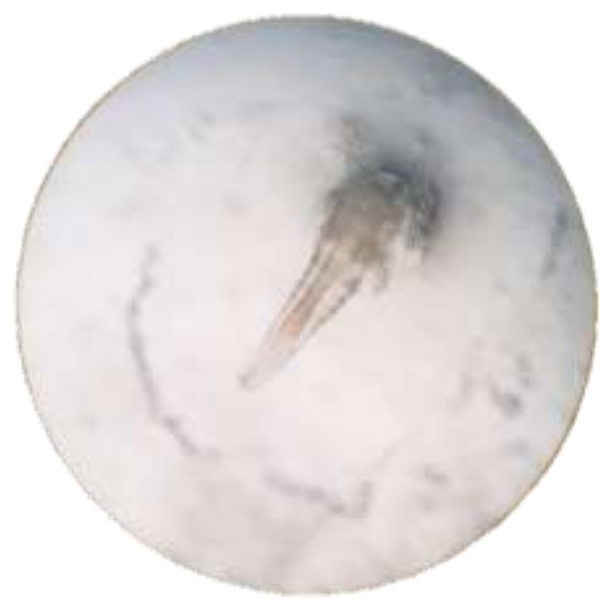

Source: Authors (2020).

For white control, $5 \mathrm{~mL}$ of the saline solution was used for positive control $\mathrm{K}_{2} \mathrm{Cr}_{2} \mathrm{O}_{7}$ and for negative control $5 \mathrm{~mL}$ of a 4 $\mathrm{mg} \mathrm{L}^{-1}$ solution of Tween 80. After 24 hours of exposure, the count of the live larvae was performed, considering dead those that did not move during observation or with the slight agitation of the vial. The criterion established by Dolabela (1997) was adopted for classification of EOs toxicity, being considered highly toxic when $\mathrm{LC}_{50} \leq 80 \mathrm{mg} \mathrm{L}^{-1}$, moderately toxic to $80 \mathrm{mg} \mathrm{L}^{-1} \leq \mathrm{LC}_{50} \geq$ $250 \mathrm{mg} \mathrm{L}^{-1}$ and toxic slightly or nontoxic when $\mathrm{LC}_{50} \geq 250 \mathrm{mg} \mathrm{L}^{-1}$. Statistical analysis of the data for the toxicity test was performed according to the Reed and Muench (1938).

\subsection{Microencapsulation}

The encapsulation test followed the methodology described by Dubey et al. (2009). Sodium alginate reagents, anhydrous calcium chloride, the EO of each species under study, distilled water and surfactant tween 80 were used for the synthesis of alginate microparticles. For the synthesis of particles with encapsulated EO, $60 \mathrm{~g}$ of sodium alginate solution $(3.5 \% \mathrm{~m} / \mathrm{v})$ were mixed with $15 \mathrm{~g}$ of tween 80 and $6 \mathrm{~g}$ of essential oil. The mixture was homogenized at 10,000 rpm and then dripd over $\mathrm{CaCl}_{2}$ solution for hardening of particles via crosslinking.

The microcapsules (Figure 3) obtained were washed with filter distilled water and dried at $35^{\circ} \mathrm{C}$ in an oven for $24 \mathrm{~h}$ (Figure 4) and 15 days at room temperature $\left(30^{\circ} \mathrm{C}\right)$. 
Figure 3. Microcapsules after washing.

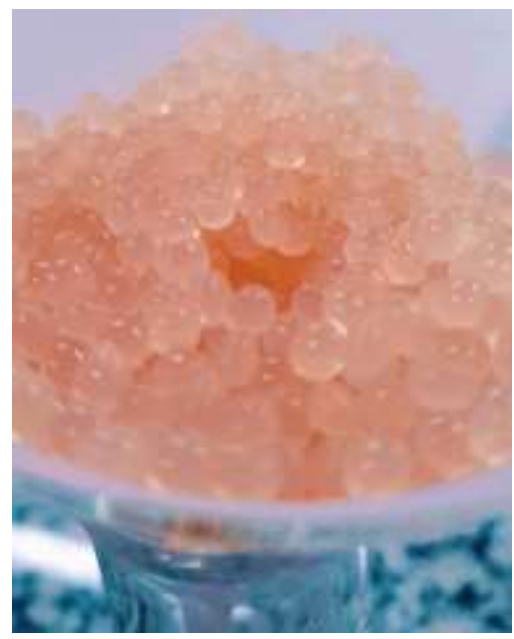

Source: Authors (2020).

The obtained products were submitted to thermal degradation and morphological characterization tests, only the microparticles within the stability patterns were used for biological assays.

Figure 4. Microparticles after initial drying process.

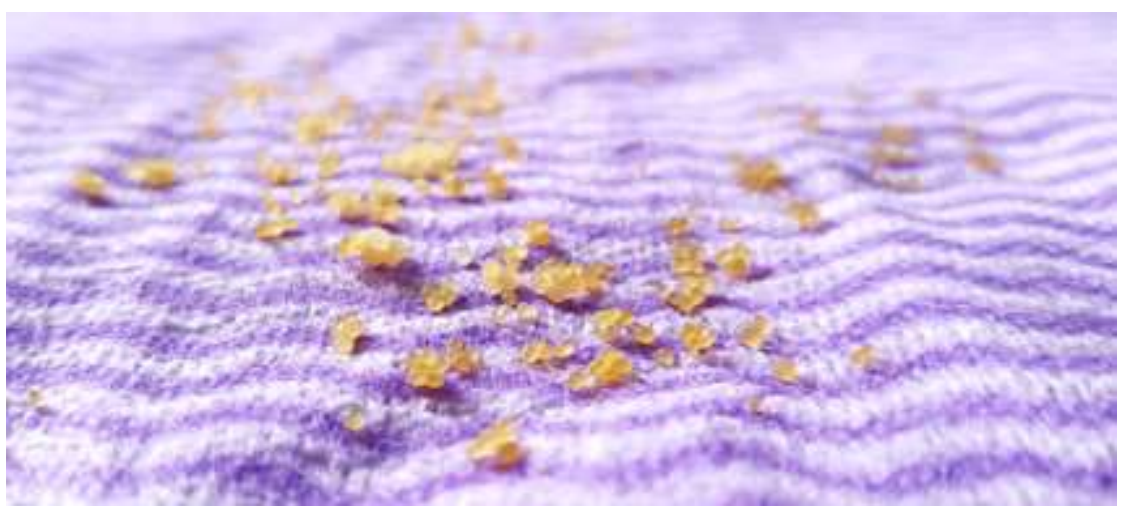

Source: Authors (2020).

For the characterization $1.2 \mathrm{~g}$ of particles containing encapsulated EO were weighed in a Falcon tube of $50 \mathrm{~mL}$ to which $15 \mathrm{~mL}$ of $\mathrm{n}$-hexane was added for the extraction of the EO. Another extraction with water was carried out for the removal of the residual tween, and the extracts and final residue were dried in an oven at $60^{\circ} \mathrm{C}$.

\subsection{Larvicidal activity}

The eggs were collected at the Federal University of Maranhão, Campus Bacanga in São Luís/ MA, through traps called ovitrampas. These consist of brown buckets $(500 \mathrm{~mL})$, polyethylene, with $1 \mathrm{~mL}$ of beer yeast and $300 \mathrm{~mL}$ of running water and inserted two eucatex reeds for mosquito egg position. The traps were inspected weekly for the replacement of reeds and egg collection. Initially, the eggs of Aedes aegypti were placed to hatch at room temperature in a circular glass aquarium containing mineral water (Figure 5). The identification of the species followed the methodology proposed by Forattini (1962). The larvae obtained were fed with cat feed according to methodology Silva et al. (1995) until they reached the third and fourth stage, the age at which the experiments were carried out. 
Figure 5. Microparticles after initial drying process.

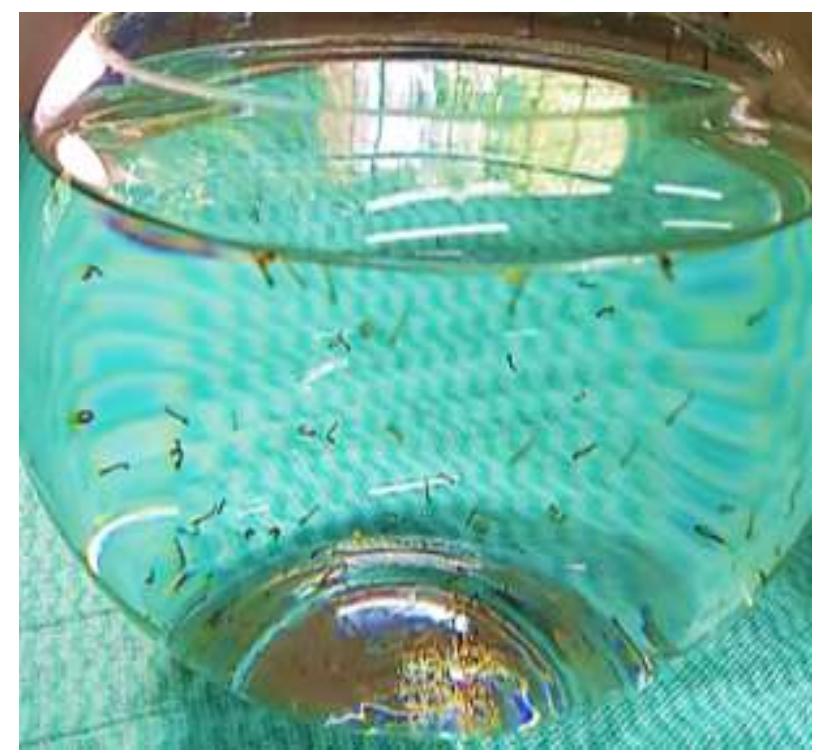

Source: Authors (2020).

The tests for larvicidal activity were carried out according to the adapted methodology proposed by Silva (2006). Initially, a mother solution of $100 \mathrm{mg}^{\mathrm{L}-1}$ of each of the EOs was prepared and diluted in $2 \%$ DMSO solution. Five dilutions were prepared from this solution at concentrations $10-90 \mathrm{mg} \mathrm{L}^{-1}$. To evaluate the larvicidal activity of the microparticles, concentrations $(\mathrm{m} / \mathrm{v})$ of them were prepared in distilled water. At each concentration of EO and microparticles, 20 larvae were added in the proportion $1 \mathrm{~mL}$ per larva. All tests were performed in triplicates and as negative control was used a solution formed of DMSO 2\%, and as a positive control, a solution of temephos at $100 \mathrm{ppm}$, equivalent to the concentration used by the National Health Foundation (FUNASA) for the larvicidal control of the vector. After 24 hours, the live and dead were found, and larvae that did not react to the touch after 24 hours of the beginning of the experiment were considered dead. The statistical analysis of the data was performed according to the Reed and Muench method (1938).

\section{Results and Discussion}

\subsection{Chemical constituents}

We identified 15 components in the EO sample of $M$. officinalis, and the majority constituents were: geranial (23.15\%) and neral (20.14\%). Studies on M. officinalis report citral as the major volatile constituent, which is a mixture of isomers, geranial ( $\alpha$-citral) and neral ( $\beta$-citral) (Pinto et al., 2015). The geranial and neral content reported in this study becomes significant when comparing with Dias (2017) that when analyzing the extract of the leaves of M. officinalis, collected at the Federa University of Paraíba, obtained the geranial (7.35\%) and neral (3.47\%) as the majority constituents of their samples. The authors recommend that the harvest be performed from 08:00 to 13:00 hours when a higher concentration of citral is observed, because high temperatures influence the quality of the EO (Nascimento et al., 2003).

The amount and range of chemical composition of EO plants of the same species in different regions may be caused by microclimatic, phytogeographic factors, plant genotypes and geographical and agronomic conditions, especially soil. However, as a general rule, the main components remain the same, only varying their concentration levels (Kumar et al., 2011).

The seasonal influence can be proven by the study conducted by Luz et al. (2014) where they analyzed the EO extracted from the leaves of $M$. officinalis collected in the summer and winter seasons, which showed quantification and qualitative 
differences in chemical compositions. Quantification by external pattern showed higher concentration of geranial and neral in the summer period (47.97\% geranial and 31.3\% 3\% neral) than in the winter period (16.61\% geranial and $9.49 \%$ neral).

EOs, as well as other natural plant extracts, have been considered as important alternatives from a phytochemical point of view, particularly due to their great variability in chemical composition. In the literature, citral, carvona and limonen chemotypes showed effective larvicidal activity with $\mathrm{LC}_{50}=7.0 \mathrm{mg} / \mathrm{mL}, \mathrm{LC}_{50}=29.8 \mathrm{mg} / \mathrm{mL}$ and $\mathrm{LC}_{50}=31.2 \mathrm{mg} / \mathrm{mL}$, respectively (Silva, 2019). Thus, it is estimated that the EO extracted in this study has larvicidal activity.

\subsection{Toxicity}

The statistical method applied allowed to obtain the concentration responsible for the mortality of $50 \%$ of larvae $\left(\mathrm{LC}_{50}\right)$ of Artemia salina (non-target organism) and the classification of $\mathrm{LC}_{50}$ was performed based on the criterion established by Dolabela (1997).

Table 1. $\mathrm{CL}_{50}$ for essential oil action against Artemia salina.

\begin{tabular}{ccc}
\hline EO & LC & Classification \\
\hline M. officinalis $\mathbf{L}$. & $295,56 \mathrm{mg} \mathrm{L}^{-1} \pm 6,10$ & Nontoxic* \\
Positive control & All inactive larvae & Toxic \\
Negative control & All active larvae & Nontoxic* \\
\hline
\end{tabular}

*LC50 above $250 \mathrm{mg} / \mathrm{L}$ Source: Authors (2020).

The EO obtained was classified as nontoxic against the non-target organism Artemia salina. The results encourage the use of this plant, since low toxicity is one of the criteria for the use of EOs as larvicides. Results described for atoxicity of $M$. officinalis by Jones et al. (2012) corroborate the data obtained in this study confirming the nontoxic potential of the EUs of this study. From a toxicological point of view, it should be considered that a medicinal plant or herbal medicine not only has immediate and easily correlated effects with its intake, but also the effects that are installed in the long term and asymptomatically, such as carcinogenic, hepatotoxic and nephrotoxic (Souza et al., 2020).

Species considered toxic produce secondary metabolites that inhalation, ingestion or contact can cause pathological changes in men and animals and, in some cases, can lead to serious disorders in the body and even death (Jesus \& Suchara, 2012). The number of poisonings caused by plants in Brazil in 2012 was 1026 cases, corresponding to $1.2 \%$ of human poisoning cases. Plants occupy the 13th place, in number of cases of intoxication with 1185 registered cases (Sinitox, 2012).

Acute or chronic intoxication caused by plants is difficult to diagnose as well as the association between symptoms and consumption and/or contact with some species is difficult to be established. In the field of public health, poisoning caused by plants has a significant impact (Campos et al., 2016). In this context, the identification of the toxicity of medicinal plants is of great relevance in the scientific and medical community, because research on the adverse and toxicological effects of these plants may contribute to the reduction of cases of human intoxication, in order to prevent accidents and elucidate questions, since studies on the variety of toxic effects of these plants will help to build a conscious thought of the moderate and sustainable use of plants (Souza et al., 2020). Thus, the EO described has in its composition chemical constituents with larvicide potentials being nontoxic for use in an application such as the synthesis of microparticles from the encapsulation of the EO of M. officinalis L. 


\subsection{Encapsulation yield}

The EO had the yield for encapsulation calculated on a percentage basis (\%) $85 \%$ indicating a good interaction between the polymer matrix and the EO. The EO of M. officinalis consists mainly of the pair of relatively small and slightly water-soluble acyclic isomer terpenes, these characteristics can be attributed to the encapsulation efficiency of the EO. Based on the literature, it can also be observed that the amount of EO initially inserted in the formulation influences the encapsulation efficiency, according to an oil saturation limit in the system and the encapsulation efficiency tends to decrease with the increase of the initial concentration of oil if it has already exceeded the saturation limit, because a satisfactory amount of polymer is necessary, so that it can coat the EO properly (Lima, 2019). Hasheminejad et al. (2019) when producing microparticles by ionic gelling, observed that increasing the initial concentration of EO in the formulation the encapsulation efficiency of clove EO in chitosan microparticles decreased significantly.

According to Xing et al. (2005), yields above 70\% are high and representative for encapsulation tests. No studies were found in the literature using alginate as a polymer matrix for encapsulation for the EOs under study. On the other hand, alginate is used in encapsulation of EOs and vegetable oils and has the encapsulation observed in this study confirmed by Pasqualim et al. (2020) and Paula et al. (2010). Encapsulation is a multifunctional technology capable of ensuring greater stability to EO and thus possible more versatility in its application.

\subsection{Larvicidal activity}

The statistical method applied allowed to obtain the concentration responsible for the mortality of $50 \%$ of larvae ( $\mathrm{LC}_{50}$ of Aedes aegypti (target organism) for the action of The EO directly and the microparticles containing the EO and the classification of $\mathrm{LC}_{50}$ was performed based on the criterion established by Cheng et al. (2003).

Table 2. Larvicidal action against Aedes aegypti of essential oils and microparticles.

\begin{tabular}{|c|c|c|c|c|c|}
\hline Species & $\begin{array}{c}\mathrm{LC}_{50} \mathrm{mg} / \mathrm{L} \\
\text { EO }\end{array}$ & $\mathbf{R}^{2}$ & $\begin{array}{c}\mathrm{LC}_{50} \mathrm{mg} / \mathrm{L} \\
\text { Microparticles }\end{array}$ & $\mathbf{R}^{2}$ & Classification \\
\hline Melissa officinalis & 40,60 & 0,9879 & 22,10 & 0,9859 & Active * \\
\hline Positive control & & & All active larvae & & \\
\hline Negative control & & & All inactive larvae & & \\
\hline
\end{tabular}

*LC50 above 100 mg/L Source: Authors (2020).

Larvicidal potential is classified according to criteria based on lethal concentration (LC), EOs that obtain $\mathrm{LC}_{50}>100$ $\mathrm{mg} \mathrm{L}{ }^{-1}$ are considered non-active, those who obtain $\mathrm{LC}_{50}<100 \mathrm{mg} \mathrm{L}^{-1}$ are considered active and those who obtain $\mathrm{LC}_{50}<50 \mathrm{mg}$ $\mathrm{L}^{-1}$ are highly active (Dias\&Moraes, 2014). Thus, the $\mathrm{EO}$ of $M$. officinalis, as well as its microparticles, showed highly effective larvicidal action by maintaining $\mathrm{LC}_{50}<50 \mathrm{mg} \mathrm{L}^{-1}$.

However, the $\mathrm{LC}_{50}$ of the larvicidal activity of the microparticles of the EO was even lower, since the EOs have a limitation of direct use, because they have a rapid volatilization, an oxidation of their chemical constituents, etc. And the microparticles obtained an even better larvicidal action, due to modulation of substance release, encouraging their potential and use.

An explanation for this larvicidal effect is the main chemical constituents present in the EO. To this end, a contribution has been made to the knowledge of new molecules with insecticide action, which can serve as substitutes for synthetic insecticides 
(Kishore et al. 2011). Studies in the literature on larvicidal activity $\mathrm{LC}_{50}$ of the EO and its microparticles of M. officinalis, in front of Aedes aegypti, are still scarce and little publicized.

However, in other studies conducted to combat Aedes aegypti, EOs with larvicidal potential were also found. In a study reported by Vera et al. (2018) when analyzing the EO of the leaves of C. flexuosus collected in the Department of Santander, Colombia, attributed the larvicidal action to the citrus constituent (geranial + neral) present in the EO.

In another study conducted by Tabari et al. (2017), the authors observed a good larvicidal and ovicidal action for the EO of Pelargonium roseum and its isolated compounds: $\beta$-citronelol, geraniol and linalool. Martins et al. (2020) tested the EO of Pimenta dioica against larvae of Aedes aegypti and concluded that the major components: eugenol, chavicol, terpineol and linalool are capable of providing a greater larvicidal effect to the mosquito. It is noteworthy that linalool is one of the non-majority components of the EO of M. officinalis, however, it can cause interactions between the other constituents and potentiate the larvicidal effect.

Several studies report insecticide activity attributed to the citrus constituent, compared to the commercial larvicidal used in the fight against dengue, temephós, recent studies regarding the susceptibility of this compound report that it is a product that over the years has lost its strength against the mosquito, and increasing doses are needed in its fight. Given the resistance to these synthetic insecticides, the EOs of plant species are by nature toxic to mosquitoes, and less aggressors to the environment (Barbosa, 2018).

\section{Final Considerations}

Finally, this study quantified the chemical constituents present in the EO of $M$. officinalis revealing compounds previously described as larvicides. The toxicity test proved that the EOs were nontoxic to the non-target organism Artemia salina. A significant yield was obtained for the encapsulation of EOs. The Aedes aegypti front lethality assay revealed relatively efficient $\mathrm{LC}_{50}$ for the EO, but an even more efficient action was reported for the microparticles, which is the main factor that drives this study to affirm the microparticles of the EOs described as an alternative in the control and combat of the vector of arboviruses Aedes aegypti.

\section{References}

Campos, S. C., Silva, C. G., Campana, P. R. V., \& Almeida, V. L. (2016). Toxicidade de espécies vegetais. Revista Brasileira de plantas medicinais, 18(1), 373382.

Coller, B. A. G., \& Clements, D. E. (2011). Dengue vaccines: progress and challenges. Current opinion in immunology, 23(3), $391-398$.

Costa, J. G. M., Rodrigues, F. F. G., Angélico, E. C., Silva, M. R., Mota, M. L., Santos, N. K. A., ... \& Lemos, T. L. G. (2005). Estudo químico-biológico dos óleos essenciais de Hyptis martiusii, Lippia sidoides e Syzigium aromaticum frente às larvas do Aedes aegypti. Revista Brasileira de Farmacognosia, 15(4), 304309.

Barbosa, C. D. O. (2018). Caracterização química e atividades biológicas dos óleos essenciais e extratos alcoólicos das espécies Ocimum spp.(manjericão) e Curcuma longa (açafrão da terra).

Dias, A. F. (2017). Variação sazonal no estudo metabolômico e na atividade antioxidante da erva-cidreira (melissa officinalis).

Dias, C. N., \& Moraes, D. F. C. (2014). Essential oils and their compounds as Aedes aegypti L. (Diptera: Culicidae) larvicides. Parasitology research, 113(2), 565-592.

Dubey, R. (2009). Microencapsulation technology and applications. Defence Science Journal, 59(1), 82.

Forattini, O. P. (1962). Entomologia médica, vol. 1. Universidade de São Paulo, São Paulo, 185-302.

Gonsalves, J. K. M. C., Costa, A. M. B., de Sousa, D. P., Cavalcanti, S. C. H., \& Nunes, R. S. (2009). Microencapsulação do óleo essencial de Citrus sinensis (L) Osbeck pelo método da coacervação simples. Scientia Plena, 5(11).

Govindarajan, M., Sivakumar, R., Rajeswary, M., \& Yogalakshmi, K. (2013). Chemical composition and larvicidal activity of essential oil from Ocimum basilicum (L.) against Culex tritaeniorhynchus, Aedes albopictus and Anopheles subpictus (Diptera: Culicidae). Experimental parasitology, 134(1), 7-11. 
Hasheminejad, N., Khodaiyan, F., \& Safari, M. (2019). Improving the antifungal activity of clove essential oil encapsulated by chitosan nanoparticles. Food chemistry, 275, 113-122.

Horta, M. A., Castro, F. I., Rosa, C. S., Daniel, M. C., \& Melo, A. L. (2011). Resistance of Aedes aegypti (L.)(Diptera: Culicidae) to temephos in Brazil: a revision and new data for Minas Gerais state. BioAssay, 6(7), 1-6.

Jesus, N. A., \& Suchara, E. A. (2013). Cultivo de plantas tóxicas e a ocorrência de intoxicações em domicílios no município de barra do garças. Revista Eletrônica Interdisciplinar, 2(10).

Jones, C. D., Woods, K. E., \& Setzer, W. N. (2012). A chemical ecological investigation of the allelopathic potential of Lamium amplexicaule and Lamium purpureum.

Kishore N, Mishra B. B, Tiwari V. K, \& Tripathi V (2011) Uma revisão sobre produtos naturais com potencial mosquitosidal. In: Tiwari VK (ed) Oportunidade, desafio e escopo de produtos naturais em química medicinal, Kerala Research Signpost 335-365

Kumar, P., Mishra, S., Malik, A., \& Satya, S. (2011). Repellent, larvicidal and pupicidal properties of essential oils and their formulations against the housefly, Musca domestica. Medical and Veterinary Entomology, 25(3), 302-310.

Lima, L. R. (2019). Caracterização e avaliação da atividade biológica de micropartículas de quitosana contendo óleos essenciais.

Luz, J. M. Q., Silva, S. M., Habber, L. L., \& Marquez, M. O. M. (2014). Produção de óleo essencial de Melissa officinalis L. em diferentes épocas, sistemas de cultivo e adubações. Revista Brasileira de Plantas Medicinais, 16(3), 552-560.

Martins, T. G. T., Everton, G. O., Rosa, P. V. S., Arruda, M. O., da Silva Souto, L. A., Fonseca, D., \& de Araújo Neto, A. P. (2020). Atividade larvicida do óleo essencial de Pimenta dioica Lindl. frente as larvas do mosquito Aedes aegypti. Research, Society and Development, 9(8), e151985518-e151985518.

Meyer, B. N., Ferrigni, N. R., Putnam, J. E., Jacobsen, L. B., Nichols, D. J., \& McLaughlin, J. L. (1982). Brine shrimp: a convenient general bioassay for active plant constituents. Planta medica, 45(05), 31-34.

Nascimento, I. D., Innecco, R., Marco, C. A., Mattos, S. H., \& Nagao, E. O. (2003). Efeito do horário de corte no óleo essencial de capim-santo. Cienc Agron, 34, $169-172$.

Ozório, R. Á. (2007). Elaboração e caracterização de micropartículas de astaxantina com quitosana.

Pasqualim, P., Culpi, T. A., Kaminski, G. T. A., Fin, M. T., Sasso, D. G. B., Costa, C. K., \& Zanin, S. M. W. (2020). Microcápsulas de alginato de cálcio e óleo vegetal pela técnica de gelificação iônica: um estudo da capacidade de encapsulamento e aplicação dermatológica. Visão Acadêmica, 11(1).

Paula, H. C., Oliveira, E. F. D., Abreu, F. O., Paula, R., Morais, S. M. D., \& Forte, M. (2010). Esferas (beads) de alginato como agente encapsulante de óleo de croton zehntneri pax et hoffm. Polímeros, 20(2), 112-120.

Pimenta, A. T., Santiago, G. M., Arriaga, Â., Menezes, G. H., \& Bezerra, S. B. (2006). Estudo fitoquímico e avaliação da atividade larvicida de Pterodon polygalaeflorus Benth (Leguminosae) sobre Aedes aegypti. Revista Brasileira de Farmacognosia, 16(4), 501-505.

Pinto, Z. T., Sánchez, F. F., Santos, A. R. D., Amaral, A. C. F., Ferreira, J. L. P., Escalona-Arranz, J. C., \& Queiroz, M. M. D. C. (2015). Chemical composition and insecticidal activity of Cymbopogon citratus essential oil from Cuba and Brazil against housefly. Revista Brasileira de Parasitologia Veterinária, 24(1), 3644.

Prophiro, J. S., Silva, O. S., Luna, J. E. D., Piccoli, C. F., Kanis, L. A., \& Silva, M. A. N. D. (2011). Aedes aegypti e Aedes albopictus (Diptera: Culicidae): coexistência e susceptibilidade ao temephos, em municípios com ocorrência de casos de dengue e diferentes características de urbanização. Revista da Sociedade Brasileira de Medicina Tropical, 44(3), 300-305.

Reed, L. J., \& Muench, H. (1938). A simple method of estimating fifty per cent endpoints. American journal of epidemiology, 27(3), 493-497.

Rothman, A. L. (2004). Dengue: defining protective versus pathologic immunity. The Journal of clinical investigation, 113(7), 946-951.

Silva, J. M. S. D. (2019). Encapsulamento do óleo essencial da Lippia alba em nanopartículas de poli-e-caprolactona (PCL) para avaliação da estabilidade e atividade larvicida contra o Aedes aegypti.

Silva, L. D. S. B., Cardoso, R. T. N., Fernandes, J. L. A., Silva, C. A., \& Eiras, A. E. (2018). Modelo entomológico determinístico sob efeito da pluviosidade para o Aedes aegypti e o Aedes albopictus. TEMA (São Carlos), 19(2), 289-303.

Silva, H. H. G. D., Silva, I. G. D., Elias, C. N., Lemos, S. P. S., \& Rocha, A. P. (1995). Idade fisiológica dos ovos de aedes (stegomyia) aegypti (Linnaeus, 1762)(diptera, culicidae).

Simões, C. M. O., Schenkel, E. P., Gosmann, G., Mello, J. C. P., Mentz, L. A., \& Pedrovick, P. R. (2010). Farmacogno sia: da planta ao medicamento [Pharmacognosy: from the Plant to the Drug]. UFRGS: Porto Alegre, Barzil.

Souza, E., Previero, C., Barros, L., \& Oliveira, A. (2020). Estudo da toxicidade de plantas medicinais comercializadas por raizeiros de Palmas-TO.

Tabari, M. A., Youssefi, M. R., Maggi, F., \& Benelli, G. (2017). Toxic and repellent activity of selected monoterpenoids (thymol, carvacrol and linalool) against the castor bean tick, Ixodes ricinus (Acari: Ixodidae). Veterinary parasitology, 245, 86-91

Vera, S. S., Zambrano, D. F., Méndez-Sanchez, S. C., Rodríguez-Sanabria, F., Stashenko, E. E., \& Luna, J. E. D. (2014). Essential oils with insecticidal activity against larvae of Aedes aegypti (Diptera: Culicidae). Parasitology Research, 113(7), 2647-2654.

Xing, F., Cheng, G., Yi, K., \& Ma, L. (2005). Nanoencapsulation of capsaicin by complex coacervation of gelatin, acacia, and tannins. Journal of applied polymer science, 96(6), 2225-2229. 